JOHN H. MCDOWELL

\title{
The Mexican Corrido
}

\section{Formula and Theme in a Ballad Tradition}

Milman PARRY's CONVERSION to an oral-formulaic perspective in the course of his Homeric studies, coupled with his field observations of the living SerboCroatian epic, enabled him to produce a systematic theory of the formulaic character of literature originating in an oral tradition. ${ }^{1}$ The dissemination of this theory, largely accomplished by Parry's student and co-worker, Albert B. Lord, ${ }^{2}$ ultimately precipitated what has been called "a revolution in scholarly opinion." 3

The oral-formulaic theory, with attendant controversy, has recently resurfaced in the pages of this journal. Bruce Rosenberg alleges the formulaic character of the spontaneous sermon; ${ }^{4}$ Bennison Gray counters with a critique encompassing both Rosenberg's application and Parry's original formulation. ${ }^{5}$ Without pausing here to discuss the many valid questions raised by Gray, I will refer to only a single far-ranging issue aired in his paper that is of crucial importance to my own: Can a method designed to illuminate features of certain texts otherwise obscured in the passage of time be employed from a literary and folkloristic perspective in approaching texts of another tradition? The present undertaking assumes an affirmative answer to this question of methodology.

The current exchange between Rosenberg and Gray brings to mind the comments of H. L. Rodgers concerning the work of F. P. Magoun and others in the field of Anglo-Saxon literature. ${ }^{6}$ Rodgers insisted on a tighter construction of the concept "formula," if conclusions based on formulaic analysis were to be valid.

\footnotetext{
1 For references see the footnotes to the first chapter of Albert B. Lord, The Singer of Tales (Cambridge, I960), numbers I through 6.

2 Ibid.

${ }^{3}$ H. L. Rodgers, "The Crypto-Psychological Character of the Oral Formula," English Studies, 47 (1966), 89-102.

4 Bruce A. Rosenberg, "The Formulaic Quality of Spontaneous Sermons," JourNaL OF AMERICAN FOLKLORE, 83 (1970), 3-20. Other recent publications by the same author include The Art of the American Folk Preacher (New York, 1970), and "The Genre of the Folk Sermon," Genre 4 ( I97I).

5 Bennison Gray, "Repetition in Oral Literature," Journal of American FolkLoRe, 84 (I97I), 289-303.

${ }^{6}$ Rodgers.
} 
The lesson contained in the Anglo-Saxon experience is that the oral-formulaic theory must be applied with creativity and precision. Indeed, one may venture to say that the better part of Gray's objections could be reduced to trivial matters of semantics if this preliminary groundwork is laid with imagination and clarity. The present paper proposes to lay some groundwork and then look at the corrido, the folk ballad of Mexico. In applying the method of formulaic analysis, the following must be accounted for: (I) the shift in genre, (2) the precise nature of a formula, and ( 3 ) the definition of the corpus.

The oral-formulaic method in its original statement applied to poetry of epic proportions. In contrast, even a long popular corrido is quite short by epic standards. The relative importance of improvisation and memorization will be affected by the length of the poem. In dealing with the ballad, however, one might expect the initial performance to rely on improvisation from a formula pool in somewhat the same way that epic performance does. Indeed, the first singing of a corrido most closely approaches the Parry-Lord paradigm. Subsequent performances afford a larger role to recitation from memory, depending on the inclination, aptitude, and training of the particular corridista. Moreover, the corrido, unlike Homeric or Serbo-Croatian epics, is stanzaic. A stanza of four lines, the typical corrido stanza, is more amenable to memorization than a long series of autonomous lines. When each line is autonomous, a single line can be added or dropped with ease. Likewise, an entire stanza can be added or dropped, but with greater impact on the overall design. Within the stanza, the poet can improvise, but his improvisation must preserve the stanza intact. The role of improvisation, or, better said, re-creation, is curtailed in the ballad by the increased practicality of memorization and by the formal restrictions imposed by stanzaic poetry. Nonetheless, we shall see that the corrido allows significant scope to re-creation through formula.

A second consideration in applying the oral-formulaic method to the corrido is the precise definition of "formula" as it is used here. After Rodgers' essay, any attempt to use the theory incurs this responsibility in the interests of basic clarity. Rodgers cites Parry's statement of the formula as "a group of words which is regularly employed under the same metrical conditions to express a given essential idea." " He points out that at each juncture in the definition some applications have disregarded the important qualifying words. "A group of words" has been taken to mean a single word. "Regular employment" has been taken to mean one recurrence in the entire corpus. And "the same metrical conditions" has been rewritten by one scholar to read "the same, or similar, or dissimilar metrical conditions." 8 Rodgers maintains that unrestricted definition of the formula can yield deceptive results.

The corrido presents a problem in only one of these areas. Formula in the corrido always encompasses at least one entire line containing several words. The formula is a metric entity in the corrido. The line is octosyllabic, and the musical phrase establishes a consistent stress pattern maintained throughout. ${ }^{9}$ The problem concerns the term "regular employment." In the absence of a concordance of line

\footnotetext{
7 Lord, 30.

8 Eduardo deChasca, "Toward a Redefinition of the Epic Formula in the Light of the Cantar of Mio Cid," Hispanic Review, 38 (r970), 257.

${ }^{9}$ See the exhaustive treatment of meter in Daniel Castañeda, El corrido mexicano (Mexico, 1943).
} 
repetition in the corrido, and because of the restricted available corpus, it will be necessary to admit to the ranks of formula lines that repeat infrequently. Their regular employment in the uncollected or unavailable corpus must be postulated.

As a preliminary, a few words must be said concerning the corpus. The corpus can be variously determined. The focus chosen in each of the three following dimensions will determine the size and character of the corpus: (I) number of singers, (2) geographical region, and (3) period of time. These choices must take into account the number of authentic texts available, the objective in mind, and the degree of formal and thematic unity in the field under consideration. For present purposes, two factors argue for the most inclusive possible focus. First, while the actual number of lines collected is considerable, the texts are often not reliable. Specifically, it is difficult to discriminate between literary and oral production. The number of corrido texts safely ascribable to oral production is not impressive. Second, a continuous line of descent linking the various manifestations of Spanish verse narrative to a common heritage can be traced. Merle Simmons has outlined the key stages in the evolution of the Spanish narrative verse tradition from the medieval romance to the contemporary corrido. ${ }^{10} \mathrm{~A}$ continuous line of descent does not imply that at all times, in all places, the tradition was active. Américo Paredes distinguishes between traditional ballads and a ballad tradition. ${ }^{11}$ The former are "survivals of a moribund tradition tentatively evolving into something else."12 A ballad tradition consists of "crystallization of those survivals at one particular time and place into a whole ballad corpus, which by its very weight impresses itself on the consciousness of the people."13 Conditions favorable to the creation of a ballad tradition occur when there is a vitality and movement of thought and people, as Joan Miller suggests. ${ }^{14}$ In the case of the corrido, it was border conflict in the North, and revolution there and elsewhere, that called forth a vigorous ballad tradition. ${ }^{15} \mathrm{~A}$ stock of formulas, as well as the poetic form, remains available in the traditional ballads of static times and isolated communities. It is, however, the thriving ballad traditions that perform re-creative operations with the traditional stock of ballad formulas.

The entire trajectory of the Spanish verse narrative tradition would make a fascinating study, but more to the point here is the remarkable tenacity of the traditional stock. Vicente Mendoza, for example, traces the vuela, vuela palomita motif back to the wedding songs of Leon. ${ }^{16} \mathrm{~A}$ sample of other corrido-like formulas found in the old romance follows.

\section{Bernardo del Carpio cabalga con un caballo morcillo \\ en su caballo Babieca}

\footnotetext{
10 Merle Simmons, "The Ancestry of Mexico's Corridos," Journal of American FolkLORE, 76 (r963), I-I 5.

11 Américo Paredes, "The Ancestry of Mexico's Corridos: A Matter of Definition," Journal of AMERICAN FolKLORE, 76 (I963), 231-235.

12 Ibid.

13 Ibid.

14 E. Joan Miller, "Rag Bag World of Balladry," Soutbern Folklore Quarterly, 24 (1960), $217-$ 225.

15 See Américo Paredes on this subject, especially "The Mexican Corrido: Its Rise and Fall," in Madstones and Twisters, ed. Mody C. Boatright et al. (Austin, 1957), 91-ro5.

16 Vicente T. Mendoza, Lírica narrativa de México (Mexico, 1964).
} 
un miércoles de mañana

a las nueve horas del día

$\mathrm{El}$ año mil cuatrocientos

cincuenta y dos ha pasado

otro día de mañana

de esta manera ha hablado. ${ }^{17}$

Each of these is found, in identical or slightly altered form, in the present-day corrido. Without expanding this set of examples, it should be apparent that the corrido echoes the romance, from which it is ultimately descended. To a remarkable extent, the entire corpus of Spanish narrative verse forms a coherent unit. As a practical matter, a broad focus will be adopted in this study, and documentation of formula recurrence will be accepted throughout the entire corpus of Spanish narrative verse.

Relatively little work has been done on formulas in the corrido. Plausible comments have been made by Armando Duvalier, although from a completely different perspective. ${ }^{18}$ In general, collectors and commentators have worked with an eye toward concerns other than formulaic analysis. The two-volume collection of corridos of the Revolution by Armando de Maria y Campos deals mostly with broadside corridos, which thus admits of literary contamination. ${ }^{19}$ The two major works published by Mendoza present similar difficulties, although to a lesser extent. ${ }^{20}$ His standard citation, "procede de ...", rarely clarifies the exact origin of the text. Simmons' study of the Revolution through corridos of the time also deals largely with broadside ballads. ${ }^{21}$ To the best of my knowledge, the only collector who has rigorously distinguished between literary and oral production is Américo Paredes. ${ }^{22}$ Most of his texts of corridos in the oral tradition were collected in the Brownsville-Matamoros area in the early r950s. Also, a collection of reliable texts was found in a commercial corridista's edition of popular corridos, published by Colección Adelita in Mexico City without author or editor. Due to the preponderance of texts from the North, the following analysis may contain a bias toward the border corrido. To offset this bias, the main text to be considered, a variant of the "Corrido de Heraclio Bernal," comes from the Adelita collection.

\section{The "Corrido de Heraclio Bernal"}

The following variant of the "Corrido de Heraclio Bernal" (henceforth referred to simply as "Heraclio Bernal") can be taken as representative of the corpus

17 All citations from Spanish romances come from three sources: D. Augustín Durán, Romancero general (Madrid, I832); Felipe C. Maldonado, Romancero español (Madrid, I963); and C. Colin Smith, Spanish Ballads (Oxford, I964).

18 Armando Duvalier as quoted in Castañeda, I8-19.

19 Armando de María y Campos, La Revolución Mexicana a través de los corridos populares (Mexico, 1962).

20 Vicente T. Mendoza, Lírica narrativa de México; and El romance español y el corrido mexi. cano (Mexico, 1939).

${ }^{21}$ Merle Simmons, The Mexican Corrido as a Source for the Interpretive Study of Modern Mexico (Bloomington, Ind., r957).

22 The tapes made by Américo Paredes are housed in the Folklore Library at the University of Texas in Austin. Professor Paredes was kind enough to lend me a personal copy of the transcriptions. A limited number of texts from this collection are contained in Américo Paredes, "Ballads of the Lower Border," M.A. thesis (University of Texas, 1953). 
of popular corridos in Mexico. Many of the common themes and formulas occur in this example. It would be a mistake, however, to assume that all corridos greatly resemble this one. Corridos vary in their formal aspects as much as in their themes. For present purposes, though, it will only be possible to focus on a single example, and therefore a more or less standard corrido has been selected. A variation on Lord's system of underlining will be employed, wherein the solid lines mark definite formulas, and the broken lines mark probable formulas whose recurrence has not yet come to my attention..$^{23}$ Here they appear as italic and boldface, respectively. In addition, lines repeated in a variant of "Heraclio Bernal" collected by Américo Paredes in the North, but not repeated elsewhere, are marked with a broken and dotted line.

Año de noventa y cuatro
y puerto de Mazatlán
por primera vez se canta
la tragedia de Bernal.
Heraclio Bernal decía
en su caballo alazán
que había de ser jefe
del puerto de Mazatlán.
Heraclio Bernal decía
cuando iba para Saucillos
que en la bolsa traía plata
y en la cintura casquillos.
Heraclio Bernal decía
cuando iba para Sonora:

-Este cuero que aquí traigo

lo quiero para tambora.-

Vuela, vuela palomita

y di subida al nopal

que diez mil pesos of recen

por la vida de Bernal.

Una familia en la sierra

estaba muy arruinada

y le dió quinientos pesos

para que se remediara.

Heraclio Bernal decia

cuando encontraba un arriero

que él no robaba a los pobres

antes les daba dinero.

Dijo doña Bernardina,

la querida de Bernal:

- Mas que la vida me cueste

yo le mando retratar.-

${ }^{23}$ Lord, 46. 
$Y$ entonces lo retrataron sobre un caballo oscuro que en medio de la Acordada se estaba fumando un puro.

Desde Torreón, de Coahuila hasta las playas del mar por todita aquella andaba no le osaban molestar.

Pero una vez en la sierra de sorpresa lo tomaron, a él y a Fabián el indito en un punto les cercaron. El indio Fabián le dijo:

-Pues esto no tiene fin aquí nos formaron sitio los Rochas del copalquín.$Y$ Heraclio Bernal decía en su caballo alazán:

-Ahora rompemos el sitio y entramos a Mazatlán.-

Heraclio Bernal decía camino de Mazatlán: -Ni un pelo nos han tocado y mira como se van.-

Dijo don Crispin García, el jefe de Mazatlán:

-Vénganse dos Acordadas y la guardia nacional.

-Vénganse dos Acordadas y la guardia nacional y vamos a Durango a traer a Heraclio Bernal.-

Y en Mazatlán lo mataron a traición y por detrás porque ese Crispin García bueno era para eso y más.

$Y$ todavía ya muerto si en la caja lo veían la Acordada y los soldados mucho miedo tenían.

Ora ricos de la costa ya no morirán de susto ya mataron a Bernal ora dormirán a gusto. 


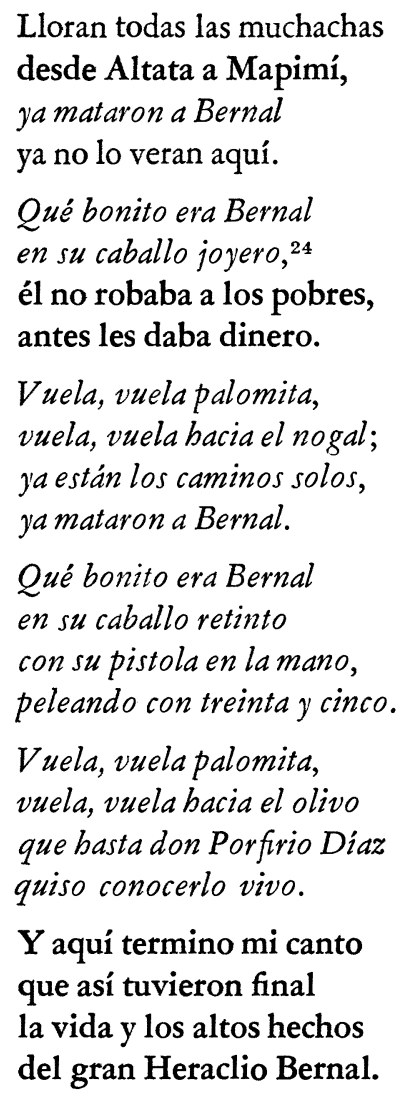

There are three degrees of certainty in the foregoing formulaic analysis. The actual formulas include the following:

( I) Año de noventa y cuatro: a common type of formula used to open corridos or to begin the narration of events within them. Similar formulas are found in the Spanish romance (El año mil cuatrocientos).

(2) y puerto de Mazatlán: forms a parallel construction with the preceding line.

(3) la tragedia de Bernal: according to Mendoza, "El vocablo tragedia implica para los corridistas el sentido de accidente, muerte violenta, o desastrada, y es frequentemente usado."25 These first three formulas correspond to the second formula in Duvalier's system.

(4) Heraclio Bernal decia: one of many formulas that serve to introduce speech events. Interestingly enough, this form is reserved to introduce the speech of the hero only; corresponds to Duvalier's third formula.

(5) en su caballo alazán: a central descriptive capsule in the corrido.

(6) cuando iba para Saucillos: like the preceding formula, combines with other formulas to form a two-line formulaic unit.

(7) Vuela, vuela, palomita/y di subida al nopal: Mendoza traces this formula back to the wedding songs of León.

24 Joyero in this line appears in other versions as jovero.

25 Mendoza, Lírica narrativa de México, 1 I. 
(8) Dijo doña Bernardina: a second form of the formula used to introduce speech events. This form is reserved for people involved in the hero's downfall.

(9) Mas que la vida me cueste: a proverbial expression, found as far back as in the romance (Abenámar) and still current (for example, a recent song by Los Relámpagos, a popular Chicano conjunto).

( Io) El indio Fabián le dijo: a neutral form introduces the speech of the hero's friend.

(II) camino de Mazatlán: another journey formula.

(I2) ya no morirán de susto: the same line is found in a similar passage in the "Corrido de Mariano Reséndez," in the Paredes collection.

(I3) ya mataron a Bernal: the use of this formula to relate the hero's death suggests that the corrido does not focus on violent action.

(I4) Qué bonito era Bernal: an exclamation of approval, as qué bonitos son los bombres in the "Corrido de Arnulfo González."

(I5) ya están los caminos solos: this line is repeated in every variant of "Heraclio Bernal" that has come to my attention.

(I6) con su pistola en la mano: a central motif, well described by Paredes. ${ }^{26}$

(I7) peleando con treinta y cinco: of the same type as the preceding formula.

(I8) que basta don Porfirio Diaz/quiso conocerlo vivo: these two lines are repeated in all the variants of "Heraclio Bernal" I have consulted.

In addition, there are a number of formulaic expressions, a category including lines repeated only in this corrido, lines closely resembling known formulas, and lines sounding formulaic, although my research has not uncovered recurrences in the corpus. The pair of lines Vénganse dos Acordadas/y la guardia nacional are repeated only in this corrido. Even so, they faintly recall the line from the romance "Delgadina"- -Juntense los once criados. A louder echo relates the line Ora ricos de la costa to Adios indios de la costa in the "Corrido de Mariano Reséndez." A line that sounds formulaic is hasta las playas del mar.

Finally, a number of lines are repeated only in one other variant of the corrido. Since one variant comes from the oral tradition in the North and the other from a recently printed collection published in Mexico City, direct borrowing is unlikely. It does not seem unreasonable, therefore, to identify these lines as formulaic.

The present formula count is tentative: it should probably be taken as a conservative estimate, in view of the limited corpus of collected, orally recorded corridos. By the most inclusive standards, the corrido is 66 percent formulaic. Excluding all questionable formulas, "Heraclio Bernal" still contains eighteen formulas, comprising 39 percent of its content.

The formulas preceding speech raise an interesting point. In his essay on formulaic expression in $E l C i d$, deChasca illustrates the poetic use of formula. ${ }^{27} \mathrm{He}$ asserts that some epithet choices are determined by considerations of internal rhyme. He also shows how the adjective bueno is increasingly applied to the Cid as his favor with the king improves. Something similar can be seen in the restriction of speech-introducing formulas in "Heraclio Bernal." A distinct form occurs for each of the three categories of speakers: the hero, the hero's friend, and the

${ }^{26}$ See Américo Paredes, "With His Pistol in His Hand": A Border Ballad and Its Hero (Austin, 1958).

${ }_{27}$ deChasca, "Toward a Redefinition." 
hero's enemies. These formulas fall on the first line of the stanza in each case and are therefore not determined by rhyme necessities.

\section{Themes in "Heraclio Bernal"}

Many of the customary themes of the corrido tradition appear in "Heraclio Bernal." Using Rosenberg's amplification of the concept, where theme is "a commonly used incident, description or idea which regardless of context, uses many of the same formulas in approximately the same sequence," 28 the following themes occur in "Heraclio Bernal."

(I) Place, date, and name of hero: literally hundreds of formulas accomplish this purpose; different degrees of exactitude are possible-one variant of "Benjamín Argumedo" invests four lines in specifying the date:

$$
\begin{aligned}
& \text { último día de febrero, } \\
& \text { novecientos dieciséis, } \\
& \text { entre las nueve y las diez } \\
& \text { Pues era un martes por cierto }
\end{aligned}
$$

(2) Self-conscious reference: por primera vez se canta; most corridos contain at the outset a reference to the performance situation.

(3) Speech event: verbal exchange or expression. "Heraclio Bernal" presents several instances of this central theme; topics include the hero's boast, battle plans, and strategies.

(4) Travel, departures, destinations: a number of formulas interact with speech events to express the theme of people in transit.

(5) The Robin Hood motif: Heraclio Bernal is the chief Robin Hood figure in the corrido tradition.

(6) Ambush, escape, capture.

(7) Self-conscious reference: $y$ aqui termino mi canto; forms a pair with the introductory reference to the performance situation.

Other corridos contain an assortment of many themes not found here. For example, the hero's farewell and the invocation theme are not present in "Heraclio Bernal." None of these themes is universal, but all are typical of a great number of corridos and collectively express the corrido world-view.

\section{Form and Formula}

To best understand the role of theme and formula in the corrido, the stanza must be viewed in its most natural units. The corridista tends to think in two-line units, in part because the last word of each pair of lines must be controlled for purposes of rhyme. Most of the stanzas in "Heraclio Bernal" exhibit this structuring; the placement of speech reflects it. Speech most often comprises a two-line unit, which is prepared for in the first two lines of the stanza:

Heraclio Bernal decía camino de Mazatlán:

-Ni un pelo nos han tocado

y mira como se van.-

28 Rosenberg, "The Formulaic Quality of Spontaneous Sermons," Io. 
Stanzas not involved in speech manifest the same characteristic. Throughout the corrido tradition, the two-line unit remains present. This two-line unit is in turn built upon shorter units in balance, such as the line and half-line. This structuring in binary units, so prevalent in oral literature, appears to be related to the esthetic and mnemonic effects of balance. ${ }^{29}$ Identification of the two-line unit as the basic building block of the corrido opens a vista into the technique underlying corrido composition.

As has been said, some formulas are themselves two-line units. In general, formulas of this type allow for substitution of the last, and rhyming, word. The vuela, vuela palomita formula permits the following rhyming pairs in "Heraclio Bernal": nopal-Bernal, nogal-Bernal, olivo-vivo. Another formula of this type occurs in the despedida, the closing reference to the performance situation, in many corridos: Ya con esta me despido/ a las bojas de un ciprés. Second-line substitution often involves several words: al pie de un verde grando; pasando por Alaquines; me compadezco de todos. In fact, the second line seems to be virtually free.

A related, but slightly different, phenomenon occurs when two isolated formulas are brought together to form a two-line formulaic unit. Several of the common single-line formulas are in free variation with others of their class. As in the case of the two-line formulas discussed above, the last word in the second line remains free for substitution. A typical pattern of this type consists of the formulaic line decía - - plus some other formulaic line. "Heraclio Bernal" offers the following examples:

\author{
Heraclio Bernal decía \\ en su caballo alazán \\ Heraclio Bernal decía \\ cuando iba para Saucillos \\ Heraclio Bernal decía \\ camino de Mazatlán
}

Other corridos also provide examples:

\title{
Decía Gregorio Cortez \\ con su pistola en la mano \\ Decía el Cherife Mayor \\ como queriendo llorar
}

Each of the formulas comprising the second line has an existence independent from the particular context it occurs in. For example, in Heraclio Bernal the formulaic line en su caballo - appears in three different contexts. While each of these formulas is found alone, they more often occur in the types of conjunction mentioned above. In this capacity they provide considerable scope for the corridista to develop and expand the verbal and emotional core of his corrido.

\footnotetext{
29 Américo Paredes, "Some Aspects of Folk Poetry," Studies in Literature and Language, 6 (1964), and 'El Corrido de José Mosqueda' as an Example of Pattern in the Ballad," Western Folklore, 17 (1958), 154-162.
} 


\section{Formula and Theme}

A ballad operates under a different esthetic than an epic and therefore presents distinct exigencies in the performance situation. The role of theme, however, seems somewhat comparable in the two genres. Each genre manipulates a set of themes provided by the values and historical experience of the people in question. Feasts, councils, arming, individual duels, and so forth are important in the Homeric world-view; letter writing, among other things, in the Serbo-Croatian world-view; guerrilla tactics and dramatic speech events in the corrido world-view.

The formulaic pool of the epic tradition serves to develop and expand the presentation of themes. Many formulas in the corrido do not serve this purpose, but rather another one. The presence of a certain number of these familiar formulas establishes the outlines of the world of the corrido. A hero is present; his steed is honey-colored; a pistol gleams in his hand. The ballad community to which these elements are native fills out the description with the sure knowledge that comes from experiencing them daily. Many formulas in the corrido signal the corrido world; on this bare stage the particular story unfolds. In contrast, the epic elaborates at length through formulaic material. As Lord found in the Serbo-Croatian epic, a good epic poet will be able to present a single theme, varying in length, in many different versions. The theme of arming a hero might be described in ten lines in the case of a minor hero, and in up to fifty lines in the case of the main hero. ${ }^{30} \mathrm{~A}$ poet will develop the various themes important in the world-view of his audience, using a greater or lesser number of formulas as the context requires. The formulaic luxuriance of the epic contrasts sharply with the economy of formula in the ballad. Nonetheless, something analogous to the use of formula in the epic occurs in the theme of verbal exchange or expression in the corrido. Development of this core theme sometimes occurs over several stanzas.

The creativity of a poet working within an oral tradition lies in his selection of formulas to present the themes of his story, as well as in the sensitive arrangement of themes. From what has been said about the economy of formula in the corrido, the scope of the former is greatly reduced. What formulaic flexibility within the theme is in fact available to the corridista?

In the case of most themes, the play of formulas is restricted to the space of only a few lines. Within this narrow space many alternative solutions are available, but the various alternatives state rather than develop the theme. For example, the theme of the introductory reference to the singing of the corrido occurs in many forms:

Para empezar a cantar

pido permiso primero

Aquí me pongo a cantar

Voy a contarles, señores

Voy a cantar estos versos, pongan mucha atención todos

Señores con atención

les diré lo que ha pasado 
En el condado del Carmen

miren lo que ha sucedido

Año de mil novecientos, presente lo tengo yo

Voy a dar un pormenor

de lo que a mí me ha pasado

This selection presents only a few of the formulaic solutions to this theme. The theme involves a reference to the performance situation, which may be accomplished by reference to the singer, the audience, or the song, or some combination of these. The reference may be explicit, as in most of the examples cited above, or implicit, as in the one where only the verb miren conveys the presence of an audience. Finally, the theme may be integrated with some other theme, as is the case in the next-to-last example above. In short, a great variety of formulaic solutions are available. In spite of this, and because of the limitations of space, the theme is not developed, but merely stated. Indeed, a corrido that lingered over this or any other detail of the kind would be, in the framework of its own expectations, unesthetic. The purpose is to establish the world of the corrido in a few quick brush strokes and get on with the story. The demand on the corridista, for which he falls back on the formulaic stock, is to quickly and effortlessly include the pertinent details and move on to the next theme.

The theme of verbal exchange or expression, however, stands apart from the other themes in its susceptibility to formulaic expansion and development. While it offers nothing like the opportunities for development in the epic, it does provide the corridista a field in which to perform analogous manipulation of his formulaic stock. This theme characterizes the corrido, at least the corrido of northern Mexico. It constitutes the main focus of many corridos and is wholly absent only in the case of special corridos, such as the first-person prisoner's lament or the lyric corrido. The corrido's unique effect lies in its exorbitant, if not exclusive, emphasis on speech events. Homer also develops the verbal exchange motif in great depth, but then he goes on to describe the ensuing battle in equal depth. The corrido, preoccupied with the words of men in mortal situations, often disdains to present with any completeness the workings of fate that brought the verbal exchange to pass. The death of Heraclio Bernal filters through impersonally and in the past tense: $y$ en Mazatlán lo mataron. The "Corrido de Gregorio Cortez" never does explicate the plot; much more important are the defiant words of the hero. Action is subordinate to speech. For this reason, the corrido takes on something of the tone of Greek tragedy, which also enters into the words of afflicted mortals at the expense of plot and descriptive detail.

Verbal exchange, or expression, is developed through the addition of stanzas. Many of the formulas found in the corrido, with the exception of those attending to such themes as date, place, or introduction of the song, can be recruited by the corridista to expand the theme of verbal exchange. Since speech events commonly comprise but two lines, formulas are used to complete the stanza, as well as to provide content for the speech evants. Several examples have been discussed in which a formula used to introduce speech plus some other formula make up the first half of a stanza, which is completed by two lines of speech. 
Heraclio Bernal decía

camino de Mazatlán:

-Ni un pelo nos han tocado

y mira como se van.-

Some examples of a number of other ways in which the corridista may prepare for speech are as follows:

\author{
Nos decía el caporal \\ como queriendo llorar \\ Gregorio le dice a Juan \\ en el rancho de Ciprés \\ Decía el Cherife Mayor \\ como era un americano \\ Decía Tito Crixell \\ a l'hora de los balazos \\ Decía Gregorio Cortez \\ abrochándose un zapato \\ Decía Jacinto Treviño \\ que se moría de la risa \\ Decía Jacinto Treviño \\ al bajar una bajada \\ Decía Ignacio Treviño \\ con muchísimo de esmero \\ Decía Vicente el Giro \\ en su yegüita alazana
}

Alonso vino de Texas de pistola y carrillera

Arnulfo se levantó llamándole la atención Ya montado en su caballo de pistola y carabina y el gringo les contestó con su sombrero en la mano

Pero ahi le dice el teniente casi para agonizar

Eduardo R. Cantú dice a su hermano Ruperto

Cuando salieron de misa su papá le platicaba

This list could be extended almost indefinitely, but by now the versatility of these speech-preparatory segments should be apparent. By manipulating them, the corridista secures room and time to develop the speech events of his corrido. The 
ones built on the decia - — are only one type among many. Others avoid reference to the speech act itself, while providing sufficient detail to enable the correct summation of the source and target of the words that follow. Still others refer indirectly to the forthcoming act of speech. While this process is not identical to the operation of formula in the epic, it does present an analogy in stanzaic form to the epic expansion of themes through formula.

The speech event tends to be highly formulaic. It covers a variety of topics, such as the hero's defiance, battle plans, and leave-takings. Some examples of speech events in which the hero expresses his defiance follow:

-Prepara bien tu pistola

porque va a haber muchos muertos

-Yo ya les tumbé el panal, ahi les dejó las abejas

-Ya les maté el gallo fino, Fero quedaron las plumas

-No corran, rinches cobardes, con un solo mexicano

-Amigos de la Acordada, quieren jugarse la vida

-Oye amigo no se vaya, falta mi contestación

-Echenme ese gringo grande pa' llevármelo de brazo

- No hay cuidado de la reata, la argolla es la que rechina

Two interesting features emerge from a consideration of these examples. First, speech events seem to be the province of ethnic taunts and jests, so common in the border corrido. Second, an element of metaphor, proverb, or allegory often enters in, as in the following lines from "Heraclio Bernal":

-Este cuero que aquí traigo

lo quiero para tambora

\section{Traditional Material and the Corrido Esthetic}

The foregoing analysis of themes in the corrido suggests the following model of the typical oral corrido, organized about its central axis:

I. introductory reference to performance

2. setting: place, date, name of principals

3. core: verbal exchange or expression, interspersed with narrative detail

4. farewell of principal

5. despedida, closing reference to performance.

The corrido is structured symmetrically. It has a beginning ( $\mathrm{I}$ and 2 above), a middle ( 3 above), and an end ( 4 and 5 above). It most of ten focuses on stirring vocal expression. Other elements in the core section provide transition between 
speech events and set the scene for them. The narrative thread of the corrido receives articulation from the moments of speech in which it periodically climaxes. The framing references to the performance situation give shape and definition to the whole. The corrido is a highly structured genre; its clear formal outlines and its emotional core are at the same time the product of the oral process and the cause of its preservation in this process.

Formulas function differently, depending on the location in the corrido of the themes they service. The themes comprising the beginning and the end of a corrido allow little formulaic development: the addition of one or a few lines to emphasize or further specify. It is the central theme that permits formulaic development akin to the enriching role of formula in the epic. With the aid of formulaic patterns, the occasions of speech multiply. In turn, the formulaic stock provides much of the content of speech events.

In the core section of the corrido, a variety of patterns playing off speech events against narrative detail are possible. The verbal exchange rarely takes place in the form of a coherent conversation. Often the hero muses to himself:

Decía Gregorio Cortez
con su pistola en la mano
- Ah, cuanto rinche cobarde
para un solo mexicano.-

When there are two conversers, their comments do not often connect into a conversation. Corridos tend to present verbal epigrams rather than dialogue. The telling exchanges in "Valentín de la Sierra" and "Benjamín Argumedo" are exceptional, not for their poignancy but for their completeness.

Speech events are distributed in a number of patterns. In some corridos, once the dramatic situation has been set up, the corrido plunges into a series of speech events. In one variant of "Jacinto Treviño," the first stanza sets the scene:

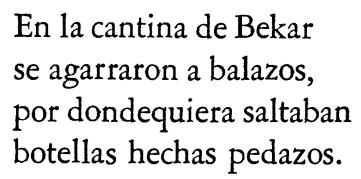

The next six stanzas relate speech events flowing from that situation, the barroom shootout. A similar arrangement occurs in "Los Sediciosos," an interesting corrido dealing with retributive violence practiced against the Mexican-American community in southern Texas. Another pattern has the two components, speech and narrative detail, alternating more or less regularly. In "Heraclio Bernal," the hero makes his pronouncements at different stages along the trajectory of his fall. Narrative detail intervenes to place the various speech events in some kind of dramatic context.

\section{Conclusion}

This paper has investigated and analyzed the role of traditional material in the corrido. At the outset, reference was made to the oral-formulaic theory of Parry and Lord, whose basic approach obtains in this paper. Certain adjustments were 
made to better accommodate the Parry-Lord method to the corrido tradition. Three major considerations emerged: (I) the shift in genre, (2) the nature of formula, and (3) the range of the corpus. With these clarifications in mind, the analysis proceeded to the role of formula and theme in the corrido, the question of form and formula, and finally the working relationship between formula and theme. It was found that the world-view of the corrido makes available to the corridista a set of themes, legends, and personages, The esthetic form of the corrido prescribes their presentation in a symmetrical design. At the beginning and end, reference is made to the fact of performance. The middle focuses on the words of men in some way challenged or afflicted. As Mendoza states it, the corrido is "un relato de diálogo directo de lineamientos dramáticos." ${ }^{31}$

The function of formulas varies within this design. The formulas expressing the themes found at the beginning and conclusion of a corrido tend to include rather than to develop their themes. On the other hand, the formulas expressing the core theme enable the corridista to expand and develop at length this nucleus of the corrido. As observation of the operation of formula reveals, the corrido moves in two-line units. Most formulas participate in this mode, while at the same time facilitating the conformance to rhyme and meter requirements. The formula thus represents a means of including the peripheral themes and developing the central theme, all within the metric and rhyme stipulations of the genre.

The formulaic character of the corrido, a ballad genre, has been established. In addition, the formulaic method has proved to be of value in discussing both the poetic and the traditional aspects of the corrido. This paper represents only a beginning. The entire historical dimension has been barely touched on. It remains to trace the continuity and innovation of theme and formula along the line of descent from romance to corrido and other contemporary forms. On the current scenario, additional fieldwork could tap the still-living corrido tradition for information on the role of creativity and memorization, the learning process, the interaction of literary and oral tradition, and other matters. Indeed, the available corpus could be subjected to a comprehensive analysis of the kind only hinted at here. All this promises not only a better understanding of the corrido, a worthy goal in its own right, but also a clearer perspective on the comportment of formula and theme in a ballad rather than in an epic tradition.

\section{The University of Texas at Austin \\ Austin, Texas}

${ }^{31}$ Mendoza, Lírica narrativa de México, I5. 